\title{
Characterization of exhaust emissions from a EURO 5 light passenger vehicle using biodiesel blends
}

\author{
I. Ribeiro ${ }^{1}$, A. Monteiro ${ }^{1}$, L. Serrano ${ }^{2,3}$, L. Tarelho ${ }^{1}$, N. Pires ${ }^{2}$, \\ P. Cascão ${ }^{4}$, S. Rafael ${ }^{1}$, O. J. Nielsen ${ }^{5}$, T. Nunes ${ }^{1}$, M. Evtyugina ${ }^{1}$, \\ M. Gameiro da Silva ${ }^{3}$, A. I. Miranda ${ }^{1}$, C. Borrego ${ }^{1} \&$ M. Lopes ${ }^{1}$ \\ ${ }^{I}$ CESAM and Department of Environment and Planning, \\ University of Aveiro, Portugal \\ ${ }^{2}$ School of Technology and Management, \\ Polytechnic Institute of Leiria, Portugal \\ ${ }^{3}$ ADAI, LAETA Department of Mechanical Engineering, \\ University of Coimbra, Portugal \\ ${ }^{4}$ Ecotech Pty Ltd, Australia \\ ${ }^{5}$ Department of Chemistry, University of Copenhagen, Denmark
}

\begin{abstract}
We have performed experiments using a EURO 5 light passenger vehicle, operated over the New European Driving Cycle (NEDC). Fuel blends containing 7\% (B7) and $20 \%$ (B20) of biodiesel ( $84 \%$ soyabean $/ 16 \%$ palm) in petroleum-based diesel were tested and compared with a diesel fuel (B0). The exhaust gases emissions were assessed for $\mathrm{NO}, \mathrm{NO}_{2}, \mathrm{SO}_{2}$ and volatile organic compounds (VOC), including a speciation analysis of VOC.

The experiment reveals that biodiesel blends improve the combustion efficiency, $\mathrm{NO}$ and $\mathrm{SO}_{2}$ emissions, and increasing $\mathrm{NO}_{2}$ and total VOC emissions. The VOC speciation analysis suggests that the type and fraction of VOC existent in exhausted gases is fuel dependent, changing their presence and concentrations according to the fuel used. Additionally, the concentration of the three main VOC species in exhaust gases from B0 (benzene, toluene and octane) decrease $60-80 \%$ if a B20 blend is used.

This experimental study contributes to a better characterization of the emission factors of EURO 5 light passenger vehicles using diesel/biodiesel blends and to a
\end{abstract}


better understanding of the impact of the use of biodiesel blends on pollutant emissions.

Keywords: biodiesel bends, EURO 5 light passenger car, New European Driving Cycle, emission measurements.

\section{Introduction}

Vehicle emissions constitute one of the main sources of atmospheric pollution in modern cities [1]. The increasing number of passenger cars, especially during the last two decades, resulted in complex traffic problems with serious consequences on emissions and fuel consumption. Additionally, diesel engines are the main power source in heavy-duty trucks and buses and their share is rapidly growing in passenger cars as well. Almost half (48\%) of new passenger cars in the Europe are based on a diesel engine [2].

Over the last years, improving engines efficiency has been a concern in reducing the fuel consumption. An example of this improvement is shown by the evolution of emission standards for road transport in Europe [3] from 1992 (EURO 1) to the present. For instances the NOx emission standards for diesel passenger vehicles decreased $91 \%$ (from 0.90 to $0.08 \mathrm{~g} \mathrm{~km}^{-1}$ ). Besides the measures to improve the engine efficiency, recent diesel cars are equipped by default with diesel particulate filter systems, which can reduce these emissions by more than $90 \%$ [4]. Moreover, these cars are equipped with an exhaust gas recirculation system which adds exhaust gas to the air-fuel mix, reducing the combustion temperature and then minimizing the production of NOx by $10-25 \%$ $[5,6]$.

On the other hand, the production and consumption of biofuels increased rapidly worldwide (from 16 billion litres in 2000 to more than 100 billion litres in 2011, according to the International Energy Agency [7] in an attempt to reduce greenhouse gas emissions, to diversify transportation fuels, promoting renewable energy and creating employment, especially in rural areas and developing countries. In the European Union, the investment in the energy sector, namely on biofuels, is one of the key strategies to meet the European commitments to the Kyoto Protocol and to develop a low carbon economy. Taking this on board the European Union's proposed scheme includes sustainability criteria for biofuels and a goal of $10 \%$ of renewable energy in the transportation sector by 2020 , as described by the European Renewable Energy Directive (2009/28/EC).

Over the last few years, several studies have been published regarding engine performance and the effects on atmospheric pollutant emissions when biodiesel is used as pure or blend fuel. Based on these studies, the review developed by [8] points out that: biodiesel effects on exhaust emissions vary significantly among vehicles, engine technology, and driving patterns. Several studies [e.g. 8-11] have been recently published contributing to the understanding of the engine behaviour regarding emission and performance profiles under specific driving cycles, such as the New European Driving Cycle (NEDC), and using different diesel/biodiesel blends. However, these studies focused on the EURO 2, EURO 3 and EURO 4 
vehicle technology classes, thus referring to emission profiles of vehicles sold from 1996 to 2009.

Due to the identified lake of information on EURO 5 (technology from 2009 to 2014) emission characterization, an experimental work was conducted to evaluate the effects of diesel/biodiesel blends on the fuel consumption and the exhaust emissions from a new diesel EURO 5 passenger vehicle, a Renault Mégane 1.5 $\mathrm{dCi}$ (2011). The emissions were characterised considering $\mathrm{CO}_{2}, \mathrm{CO}, \mathrm{NO}_{2}, \mathrm{NO}$, VOC and particulate matter (PM). However, just $\mathrm{NOx}\left(\mathrm{NO}_{2}\right.$ and $\left.\mathrm{NO}\right), \mathrm{SO}_{2}$ and VOC are presented in this document. For more detailed information the readers are invited to consult [13].

The study was made using the vehicle in a NEDC on a laboratory chassis dynamometer. Fuel blends containing $7 \% \mathrm{v} / \mathrm{v}$ (B7) and $20 \% \mathrm{v} / \mathrm{v}$ (B20) of soyabean/palm biodiesel $(84 \% / 16 \%)$, in volume basis, in petroleum-based diesel were tested and compared with a $100 \%$ diesel fuel (B0).

\section{The test procedure}

The vehicle used in this experiment was a Renault Mégane $1.5 \mathrm{dCi}$ (2011) equipped with a common-rail direct injection diesel engine and meeting EURO 5 emission standards. The technical specifications of the vehicle are listed in Table 1. This vehicle was selected because it is the most sold vehicle in Portugal with 7324 units sold between January and October 2011 [14].

Table 1: Technical specifications of the test vehicle.

\begin{tabular}{ll}
\hline Engine type & Renault Mégane 1.5 dCi \\
\hline Fuel injection system & Direct injection, common-rail \\
Cylinders/valves & $4 / 8$ \\
Displacement $\left(\mathrm{cm}^{3}\right)$ & 1461 \\
Maximum power $\left(\mathrm{kW} \cdot \mathrm{hP}^{-1}\right)$ & $81 / 110$ \\
Maximum torque $(\mathrm{Nm})$ & $240 / 1750 \mathrm{rpm}$ \\
Weight $(\mathrm{kg})$ & 1215 \\
Aerodynamic $\left.\left(\mathrm{S}^{-1} \mathrm{M}^{2}\right) / \mathrm{Cd}\right)$ & $2.21 / 0.326$ \\
Equipped with a DPF system & self-regenerating \\
Equipped with a EGR system & - \\
\hline
\end{tabular}

This vehicle, as all modern diesel cars, is equipped with diesel particulate filter systems in order to fulfil the requirements of EURO 5 standard. This vehicle is also fitted with an exhaust gas recirculation system.

Fuel blends containing $7 \% \mathrm{v} / \mathrm{v}$ (B7) and $20 \% \mathrm{v} / \mathrm{v}$ (B20) of soyabean/palm biodiesel $(84 \% / 16 \%)$, in volume basis, were tested and compared with a $100 \%$ diesel fuel (B0). The fuel properties are presented in Table 2.

It is relevant to note the main differences when comparing biodiesel with fossil diesel: biodiesel is more viscous, fuel diesel has a higher heating value, biodiesel is denser and it has about $10-11 \%$ of oxygen content while petroleum-based diesel does not have oxygen. These factors will influence the combustion process and, namely the fuel consumption and emission factors for gaseous and particulate pollutants. 
Table 2: Fuel properties used in the experiment.

\begin{tabular}{lllll}
\hline Parameter/unit & B0 & B7 & B20 & Test method \\
\hline Density at $15^{\circ} \mathrm{C}\left(\mathrm{kg} \cdot \mathrm{m}^{-3}\right)$ & 837.0 & 840.1 & 846.0 & EN ISO 3675 \\
Viscosity at $40{ }^{\circ} \mathrm{C}\left(\mathrm{mm}^{2} \cdot \mathrm{s}^{-1}\right)$ & 2.430 & 2.845 & 2.980 & EN ISO 3104 \\
Flash point $\left({ }^{\circ} \mathrm{C}\right)$ & $>55$ & 74.5 & 76.5 & EN ISO 2719 \\
Water content $\left(\mathrm{mg} \cdot \mathrm{kg}^{-1}\right)$ & $<50$ & 105 & 171 & EN ISO 12937 \\
Calculated cetane index & 51.8 & 51.9 & 52.1 & EN ISO 4264 \\
FAME content $[\%(\mathrm{v} / \mathrm{v})]$ & $<0.1$ & 6.9 & 20.0 & EN 14078 \\
Heating value $\left(\mathrm{MJ} \cdot \mathrm{kg}^{-1}\right)$ & 45.598 & 45.146 & 44.418 & ASTM D-240 \\
Distillation & & & & \\
$\quad$ Recovered at $250^{\circ} \mathrm{C}[\%(\mathrm{v} / \mathrm{v})]$ & 36 & 34 & 27 & EN ISO 3405 \\
$\quad$ Recovered at $350^{\circ} \mathrm{C}[\%(\mathrm{v} / \mathrm{v})]$ & 93 & 93 & 93 & EN ISO 3405 \\
$\quad 95 \%$ recovered $\left({ }^{\circ} \mathrm{C}\right)$ & 361.6 & 359.5 & 357.1 & EN ISO 3405 \\
\hline
\end{tabular}

The experiments were carried out with the vehicle placed over a chassis dynamometer (Figure 1a)), according to the NEDC (Figure 1b)), simulating the typical usage of a car in Europe, in order to quantify vehicle emissions under distinct driving conditions.

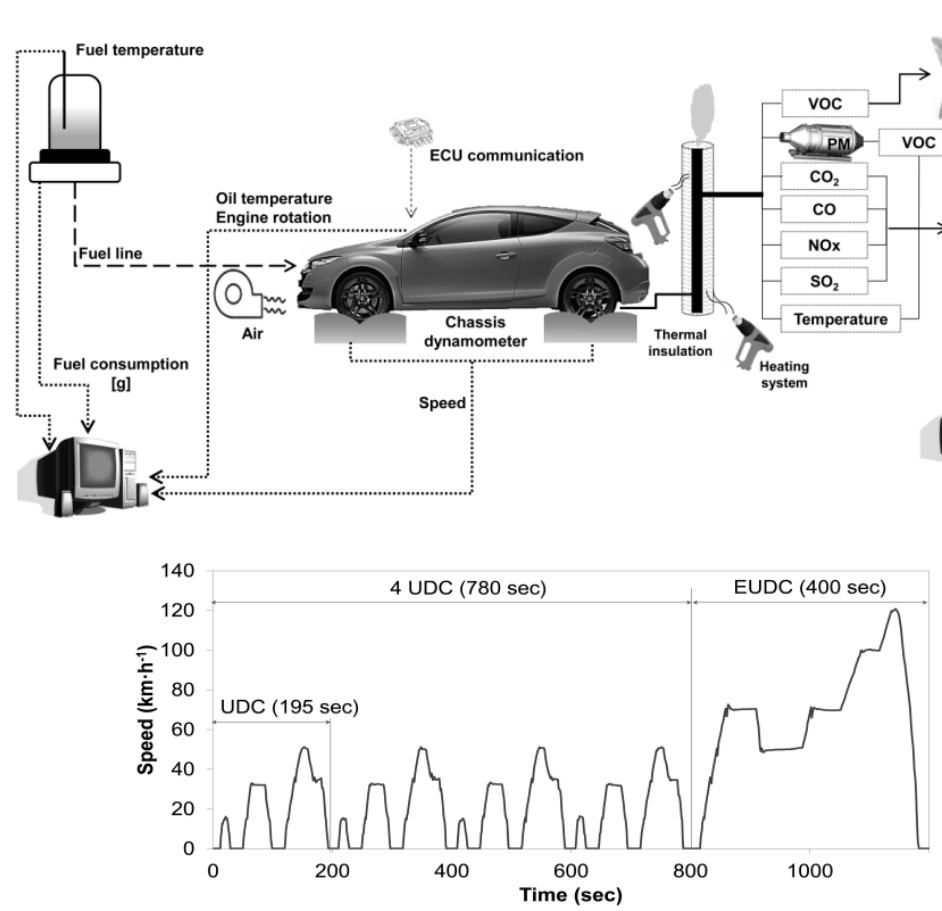

a)

Figure 1: a) Scheme of the experimental infrastructure and b) speed profile of the New European Driving Cycle (NEDC). 
To assure the comparability of the emission measurements, the NEDC was repeated four times for each fuel blend and each first replica was not considered in data analysis in order to minimize the impacts of the fuel change on the engine performance. Moreover, the exhaust gases and the engine coolant temperatures were approximately $100^{\circ} \mathrm{C}$ and $80^{\circ} \mathrm{C}$, respectively, at the start of the test procedure, to guarantee that each trial was performed at the same conditions. Thus, the concentration measurements were performed under hot conditions.

The monitoring of $\mathrm{NO}_{2}, \mathrm{NO}, \mathrm{SO}_{2}$ and total $\mathrm{VOC}$ concentrations was carried out on-line and continuously, which allows the understanding of the complete exhaust pollutant concentration profile over the NEDC conditions. Samples of exhausted gas were collected using Tedlar bags in order to perform VOC speciation analysis by gas chromatography according to the methodology described by [15]. The specifications of the measurement equipment is described in detail in [13].

\section{Results and discussion}

Table 3 compiles the fuel consumption and the mass air flow measured as indicator of the engine behaviour during the trials carried out, as well as the mass flow rates of exhaust gases determined according to the principle of mass conservation and

Table 3: Fuel consumption, mass air flow, and exhaust gas flow rates in mass and volume basis, by fuel and for each driving cycle of the experimental work.

\begin{tabular}{|c|c|c|c|c|c|c|}
\hline \multirow{2}{*}{$\begin{array}{l}\text { Fuel } \\
\text { type }\end{array}$} & \multirow{2}{*}{$\begin{array}{c}\text { Driving } \\
\text { cycles }\end{array}$} & \multicolumn{2}{|c|}{$\begin{array}{c}\text { Fuel Consumption } \\
\left(\left(1 \cdot 100 \mathrm{~km}^{-1}\right)\right.\end{array}$} & \multirow{2}{*}{$\begin{array}{c}\text { Mass air } \\
\text { flow } \\
\left(\mathrm{kg} \cdot \mathrm{h}^{-1}\right)\end{array}$} & \multirow{2}{*}{$\begin{array}{c}\text { Exhaust } \\
\text { mass flow } \\
\left(\mathbf{k g} \cdot \mathbf{h}^{-1}\right)\end{array}$} & \multirow{2}{*}{$\begin{array}{c}\text { Exhaust } \\
\text { volumetric flow } \\
\left(\mathrm{Nm}^{3} \cdot \mathrm{h}^{-1}\right)\end{array}$} \\
\hline & & Range & Average & & & \\
\hline \multirow{3}{*}{ B0 } & UDC & $\begin{array}{c}6.32- \\
6.47\end{array}$ & 6.33 & 30.96 & 31.65 & 24.61 \\
\hline & EUDC & $\begin{array}{c}5.56- \\
5.64\end{array}$ & 5.59 & 65.55 & 93.23 & 72.48 \\
\hline & NEDC & $\begin{array}{c}5.84- \\
5.94\end{array}$ & 5.86 & 48.26 & 52.52 & 40.83 \\
\hline \multirow{3}{*}{ B7 } & UDC & $\begin{array}{c}6.35- \\
6.48\end{array}$ & 6.44 & 32.22 & 32.35 & 25.14 \\
\hline & EUDC & $\begin{array}{c}5.56- \\
5.67\end{array}$ & 5.61 & 64.78 & 94.36 & 73.34 \\
\hline & NEDC & $\begin{array}{l}5.89- \\
5.97\end{array}$ & 5.92 & 48.50 & 53.37 & 41.48 \\
\hline \multirow{3}{*}{ B20 } & UDC & $\begin{array}{l}6.27- \\
6.37\end{array}$ & 6.31 & 30.78 & 31.65 & 24.60 \\
\hline & EUDC & $\begin{array}{c}5.53- \\
5.50\end{array}$ & 5.53 & 65.28 & 92.71 & 72.05 \\
\hline & NEDC & $\begin{array}{c}5.79- \\
5.84\end{array}$ & 5.82 & 48.03 & 52.35 & 40.69 \\
\hline
\end{tabular}


the volumetric flow rate based on the estimation of the densities of each product. It should be noticed that the consumptions presented correspond to the mean value of the tests performed for each fuel, with the distinction between the respective driving cycles, whereby the flows obtained are presented as mean flows.

The fuel consumption and the mass air flow are similar among the different used fuel blends. Therefore there was no noticeable effect of the use of biodiesel in the diesel engine operation.

The emission factors (EF) were calculated taking into account the volumetric flow rate for each fuel type analysed and each driving cycle (UDC and EUDC), the speed and the pollutant concentration measured on a dry basis. In order to establish the comparison between the different fuels analysed, mass concentrations were corrected for standard conditions (temperature and pressure). Since the Portuguese Decree No. 677/2009, of June 23, establishes the emission limit values applicable to combustion plants, especially on internal combustion engines, to an oxygen content of $15 \%$, this was the value used in the correction of oxygen.

Various nitrogen-based components are formed during the combustion process on a diesel engine, in particular $\mathrm{NO}$ and $\mathrm{NO}_{2}$. The formation of $\mathrm{NOx}$ depends mainly on the oxygen available, the local combustion temperatures and the load conditions [16]. The nitrogen oxides emission factors obtained by fuel type and driving cycle are presented in Figure 2.

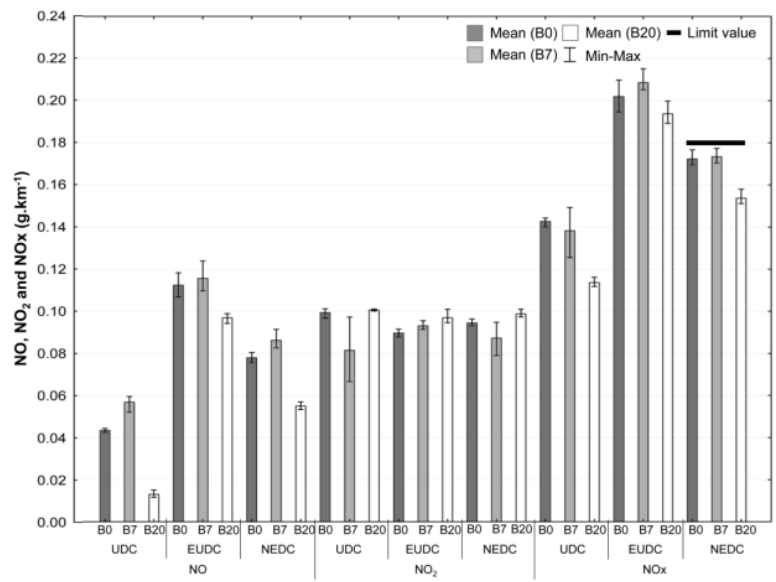

Figure 2: $\mathrm{NO}, \mathrm{NO}_{2}$ and $\mathrm{NOx}\left(\mathrm{NO}+\mathrm{NO}_{2}\right)$ emission factors by fuel type and driving cycle, and the emission limit value indicated by the $\mathrm{EC}$ Regulation 715/2007.

Looking at the complete driving cycle, the NOx emissions are below the EURO 5 limit value for all blends $\left(0.18 \mathrm{~g} \cdot \mathrm{km}^{-1}\right.$, EC Regulation $\left.715 / 2007\right)$. Typically, the NOx produced by a combustion reaction on a diesel engine is about $98 \%$ NO [16]. However, the experimental results point out a distribution of about $50 \%$ of NO and $50 \%$ of $\mathrm{NO}_{2}$, which means that the combustion processes occurred in the presence of excessive $\mathrm{O}_{2}$, allowing the oxidation of $\mathrm{NO}$ to $\mathrm{NO}_{2}$ from the motor to the tailpipe. 
B20 was the fuel with lower NOx emission factors $\left(0.15 \mathrm{~g} \cdot \mathrm{km}^{-1}\right.$ over NEDC) with a reduction of $10.8 \%$ and $11.4 \%$, when compared to $\mathrm{B} 0$ and $\mathrm{B} 7$, respectively. Furthermore, the trend of NO emissions for each fuel is similar to NOx. This can be explained by the reduced need of air and fuel (see Table 3 ) of B20, since NO is mainly formed during the combustion process, in other words, B20 promotes a more efficient combustion.

The exhaust gas temperatures of $\mathrm{B} 20$ and $\mathrm{B} 0$ are similar $\left(109.1^{\circ} \mathrm{C}\right.$ and $109.0^{\circ} \mathrm{C}$ for $\mathrm{B} 0$ and $\mathrm{B} 20$, respectively) and higher than $\mathrm{B} 7\left(100.4^{\circ} \mathrm{C}\right)$, which could explain the lower $\mathrm{NO}_{2}$ emissions associated to $\mathrm{B} 7$ over UDC and NEDC, due to $\mathrm{NO}_{2}$ being mainly formed by the Zeldovich mechanism [17].

Besides the results not displaying a clear trend, they point out to a decrease of NOx emissions, mainly due to the increase of combustion efficiency with higher mixture rates of biodiesel. The improvement of combustion efficiency is probably due to the increase of the blend's viscosity (biodiesel is more viscous than diesel - see Table 2), which can play an important role in improving the lubrication of the injection metallic components of the engine.

The $\mathrm{SO}_{2}$ present in exhaust gas is entirely due to the sulphur content of the fuel. As Table 2 shows, the fuels used in these set of tests had higher sulphur content than the maximum allowed in Europe (10 ppm) by EN 590:2009. In this sense, the $\mathrm{SO}_{2}$ emission factor obtained should be only analysed as variations between $\mathrm{B} 7$ and $\mathrm{B} 20$ regarding pure diesel (Figure 3 ).

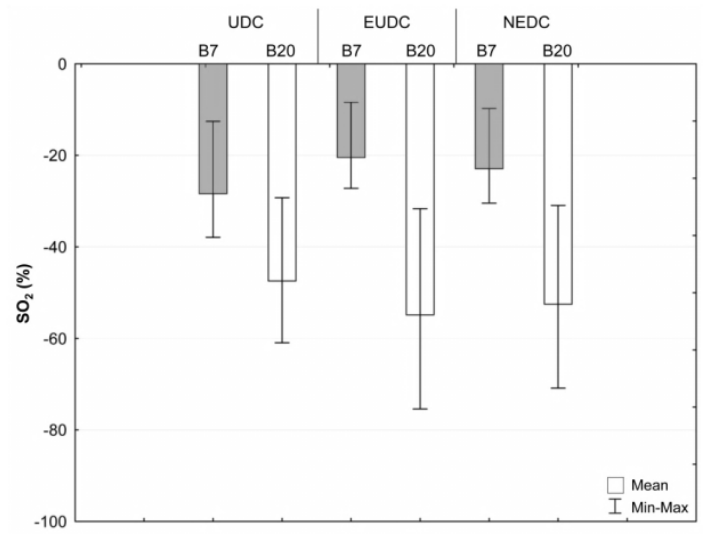

Figure 3: Variation on $\mathrm{SO}_{2}$ emission factor by fuel type and driving cycle, relative to pure diesel (B0).

Figure 3 confirms the positive influence of the use of biodiesel blended in diesel. The obtained results show a reduction on $\mathrm{SO}_{2}$ emission factor compared with pure diesel, in more than $20 \%$ using B7 and more that $50 \%$ using B20, over the UDC, EUDC and NEDC.

As described in section 2, two different kinds of measurements of VOC concentrations took place during the experiments: (1) through the flame ionization detector total VOC concentrations were measured per minute; and (2) a sample of 
exhausted gases was collected into a bag during the third UDC and EUDC of each NEDC in order to perform a VOC speciation analysis by gas chromatography. Figure 4a) represents the total VOC emissions from the three fuels used, and Figure $4 \mathrm{~b}$ ) shows the concentration of a set of VOC species found in the exhaust gas.

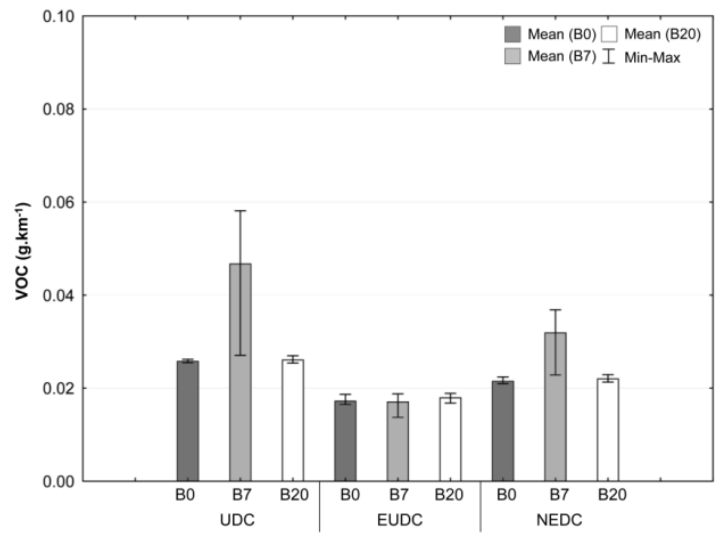

(a)

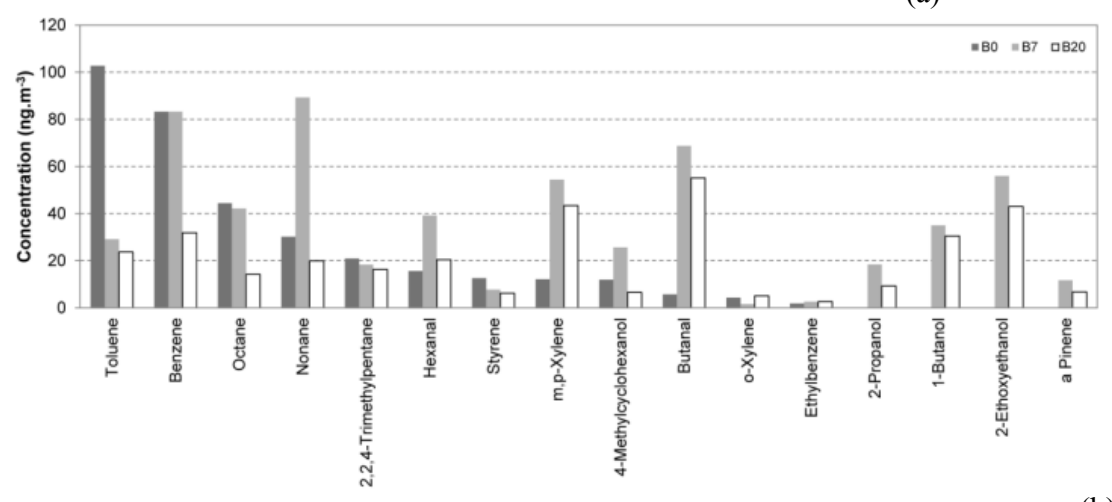

Figure 4: Total VOC emission factor (a), and concentration of some species of VOC, for B0, B7 and B20 (b).

Compared with pure diesel, the B7 fuel displays higher values of total VOC emissions (Figure 4a), especially over the UDC, while the B20 fuel presents similar values to B0. However, the comparison between B7 and B20 fuels indicates that total VOC emissions decrease with higher biodiesel rates. Lower emissions may result from higher cetane number and oxygen content for B20 fuels. Fuels with high cetane number can reduce ignition delay and help promote more complete combustion, which could lead to the reduction of hydrocarbon emissions. In addition, higher oxygen content in B20 fuel helps to combust completely and to reduce emissions [18]. 
Gas chromatography results (Figure 4b) show that the set of VOC species and their concentrations change according to the fuel blend used. Sixteen different VOC species were found in B7 and B20, instead of the twelve presented on exhaust gases from experiments with pure diesel (B0). The set of dominant VOC (species with concentration above $50 \mathrm{ng} \cdot \mathrm{m}^{-3}$ ) regarding pure diesel is characterized by the presence of benzene $(25.9 \%)$, toluene $(21.1 \%)$ and octane $(18.1 \%)$. On the other hand the set of dominant VOC for B7 includes nonane $(16.0 \%)$, benzene $(13.7 \%)$, butanal (11.1\%), m,p-xylene $(10.6 \%)$ and 2-ethoxyethanol $(8.9 \%)$. Finally, for B20 the main VOC are butanal $(18.3 \%)$ and $\mathrm{m}, \mathrm{p}$-xylene $(14.1 \%)$. The obtained results point out that the concentration of the three main VOC species in exhaust gases from B0 (benzene, toluene and octane) decrease between 60 and $80 \%$ if a B20 blend is used.

It is also interesting to verify that specific VOC species may appear in exhaust gases if a biodiesel blend is used as fuel instead of pure diesel, namely 2-propanol, 1-butanol, 2-ethoxyethanol, $\alpha$-pinene.

In accordance with [19] the dominant VOC of pure diesel engine exhausts have the highest chronic hazard quotients and hazard indices than VOC from B20. Thus, the use of pure diesel is more harmful for human health than biodiesel blends, in terms of VOC emissions.

\section{Final remarks}

The influence of B7 and B20 biodiesel blends on the fuel consumption and the exhaust gas emissions patterns of a EURO 5 light passenger vehicle operating over the New European Driving Cycle (NEDC) were assessed.

The analysis of NOx within the set of fuels tested allows the confirmation that B20 was the better blend in terms of emissions and also combustion efficiency. The opposite was found with B7. In the combustion chamber, the NO emissions decrease in the presence of B20, when compared to B0. On the other hand, after the combustion, $\mathrm{NO}_{2}$ emissions increase with $\mathrm{B} 20$ and decrease with $\mathrm{B} 7$. This occurred mainly because B20 allows higher combustion temperature (due to a better efficiency) than B7 and B0.

The results show a positive influence of the use of biodiesel blended in diesel in the $\mathrm{SO}_{2}$ emissions. Regarding the complete NECD is possible to reduce $\mathrm{SO}_{2}$ emission factor from pure diesel in more than 20\% using B7 and 50\% using B20.

The experiments performed show that total VOC emissions may increase with biodiesel blend ratios. However the set of VOC species present on exhausted gases is highly dependent on the fuel blend used. B0 presents VOC species with harmful effects to human health.

One of the central results of this experiment is that the use of B7 may imply higher emissions than B0 and B20. This may be explained by the lower combustion temperature that occur when B7 is used, which probably destabilized the combustion and catalyst processes and thus increasing the fuel consumption and NOx and VOC emissions. 


\section{Acknowledgements}

The authors acknowledge the financial support of project BIOGAIR (PTDC/AACAMB/103866/2008; FCOMP-01-0124-FEDER-008587), supported in the scope of the Competitiveness Factors Thematic Operational Programme (COMPETE) of the Community Support Framework III and by the European Community Fund FEDER. An acknowledgement to the Portuguese 'Ministério da Ciência, da Tecnologia e do Ensino Superior' for the Ph.D grant of Isabel Ribeiro (SFRH/BD/60370/2009) and the post-doc grant of Alexandra Monteiro (SFRH/BPD/63796/2009). The authors are also grateful to PRIO Energy for providing the biodiesel for this study. Ole John Nielsen thanks the Villum Kann Rasmussen Foundation for financial support.

\section{References}

[1] Monteiro, A., Miranda, A. I., Borrego, C., and Vautard, R., "Air quality assessment for Portugal," Sci. Total Environ., vol. 373, no. 1, pp. 22-31, Feb. 2007.

[2] ACEA, "Diesel Market Highly Developed in Europe," 2010.

[3] Vestreng, V., Ntziachristos, L., Semb, A., Reis, S., Isaksen, I. S. A., and Tarrasón, L., "Evolution of NOx emissions in Europe with focus on road transport control measures," Atmos. Chem. Phys., vol. 9, no. 4, pp. 15031520, 2009.

[4] Tente, H., Gomes, P., Ferreira, F., Amorim, J. H., Cascão, P., Miranda, A. I., Nogueira, L., and Sousa, S., "Evaluating the efficiency of Diesel Particulate Filters in high-duty vehicles: Field operational testing in Portugal," Atmos. Environ., vol. 45, pp. 2623-2629, 2011.

[5] Abd-Alla, G. H., "Using exhaust gas recirculation in internal combustion engines: a review," Energy Convers. Manag., vol. 43, no. 8, pp. 1027-1042, May 2002.

[6] Kašpar, J., Fornasiero, P., and Hickey, N., "Automotive catalytic converters: current status and some perspectives," Catal. Today, vol. 77, no. 4, pp. 419-449, Jan. 2003.

[7] OECD/IEA, "Technology Roadmap - Biofuels for Transport," 2011.

[8] Xue, J., Grift, T. E., and Hansen, A. C., "Effect of biodiesel on engine performances and emissions," Renew. Sustain. Energy Rev., vol. 15, no. 2, pp. 1098-1116, Feb. 2011.

[9] Karavalakis, G., Stournas, S., and Bakeas, E., "Effects of diesel/biodiesel blends on regulated and unregulated pollutants from a passenger vehicle operated over the European and the Athens driving cycles," Atmos. Environ., vol. 43, no. 10, pp. 1745-1752, Mar. 2009.

[10] Kousoulidou, M., Ntziachristos, L., Fontaras, G., Martini, G., Dilara, P., and Samaras, Z., "Impact of biodiesel application at various blending ratios on passenger cars of different fueling technologies," Fuel, vol. 98, pp. 88-94, Aug. 2012. 
[11] Karavalakis, G., Boutsika, V., Stournas, S., and Bakeas, E., "Biodiesel emissions profile in modern diesel vehicles. Part 2: Effect of biodiesel origin on carbonyl, PAH, nitro-PAH and oxy-PAH emissions.," Sci. Total Environ., vol. 409, no. 4, pp. 738-47, Jan. 2011.

[12] Karavalakis, G., Deves, G., Fontaras, G., Stournas, S., Samaras, Z., and Bakeas, E., "The impact of soy-based biodiesel on PAH, nitro-PAH and oxy-PAH emissions from a passenger car operated over regulated and nonregulated driving cycles," Fuel, vol. 89, pp. 3876-3883, 2010.

[13] Lopes, M., Serrano, L., Ribeiro, I., Cascão, P., Pires, N., Rafael, S., Tarelho, L., Monteiro, A., Nunes, T., Evtyugina, M., Nielsen, O. J., Gameiro da Silva, M., Miranda, A. I., and Borrego, C., "Emissions characterization from EURO 5 diesel/biodiesel passenger car operating under the new European driving cycle," Atmos. Environ., vol. 84, pp. 339-348, Feb. 2014.

[14] ACAP, "Estatísticas do Sector Automóvel," Lisboa, Portugal, 2010.

[15] Evtyugina, M., Calvo, A. I., Nunes, T., Alves, C., Fernandes, A. P., Tarelho, L., Vicente, A., and Pio, C., "VOC emissions of smouldering combustion from Mediterranean wildfires in central Portugal," Atmospheric Environment, vol. 64. pp. 339-348, 2013.

[16] Sun, J., Caton, J. A., and Jacobs, T. J., "Oxides of nitrogen emissions from biodiesel-fuelled diesel engines," Progress in Energy and Combustion Science, vol. 36. pp. 677-695, 2010.

[17] Lavoie, G., Heywood, J., and Keck, J., "Experimental and Theoretical Study of Nitric Oxide Formation in Internal Combustion Engines," Combust. Sci. Technol., vol. 1, no. 4, pp. 313-326, Feb. 1970.

[18] Peng, C.-Y., Yang, H.-H., Lan, C.-H., and Chien, S.-M., "Effects of the biodiesel blend fuel on aldehyde emissions from diesel engine exhaust," Atmos. Environ., vol. 42, no. 5, pp. 906-915, Feb. 2008.

[19] Peng, C.-Y., Lan, C.-H., and Yang, C.-Y., "Effects of biodiesel blend fuel on volatile organic compound (VOC) emissions from diesel engine exhaust," Biomass and Bioenergy, vol. 36. pp. 96-106, 2012. 